\title{
A case-control study of lung cancer in a cohort of workers potentially exposed to slag wool fibres
}

\author{
Otto Wong, Donna Foliart, Lisa S Trent
}

\begin{abstract}
A cohort of 4841 men were identified as having worked for more than a year at nine slag wool plants. Some of these men were potentially exposed to man made vitreous fibres (MMVF). The vital status of the entire cohort was ascertained to the end of 1989 . Of the 504 deaths that occurred between 1970 and 1989, 61 were attributed to lung cancer (cases). Individually matched controls were randomly selected from the remaining deaths. Attempts were made to locate and interview the surviving families of the cases and controls. The families of three lung cancer cases could not be located and no matched controls were found for another three cases. Included in the final analysis were 55 cases and 98 controls. Estimates of individual exposure to MMVF were based on employment records and industrial hygiene surveys. Data on smoking and histories of employment outside the MMVF industry were obtained from telephone interviews and employment records. Relative risks were calculated for cigarette smoking and exposure to MMVF. No increased risk of lung cancer was found associated with exposure to MMVF, and analysis by cumulative fibre exposure did not indicate any trend. As expected, cigarette smoking was found to be responsible for the observed increase in mortality from lung cancer in this group of MMVF workers, and the risk increased with increasing pack-years of cigarette smoking.
\end{abstract}

Man made vitreous fibre (MMVF) is used extensively in thermal and acoustic insulation. In the United States there are two major types of MMVF, fibrous glass wool and slag wool. Slag wool fibres are

Applied Health Sciences, 181 Second Avenue, Suite 628, PO Box 2078, San Mateo, CA 94401, USA O Wong

ENSR Health Sciences, 1320 Harbor Bay Parkway, Alameda, CA 94010, USA

Donna Foliart, Lisa S Trent produced by spinning or blowing molten slag from metallic ore refining processes into fibre. In the past some source materials-namely, rock or slag-and some production facilities were contaminated with asbestos or arsenic.

Because of the widespread use, the potential health effects of exposure to MMVF have been studied by many investigators. Only two large scale epidemiological studies have been carried out, however. These are the International Agency for Research on Cancer (IARC) study in Europe and the University of Pittsburgh study in the United States. For workers exposed to slag wool, the IARC study reported a modest increase in mortality from lung cancer, but no upward trend was found by duration of employment. ${ }^{1}$ The University of Pittsburgh study reported ao similar raised risk of lung cancer among 1846 slag wool workers. ${ }^{2}$ No upward trend was detected in theo American investigation either. Furthermore, the? findings from both studies were confounded by smoking and contamination with arsenic or asbestos, and much of the excess was found among very short term workers. ${ }^{1-4}$

The currently available epidemiological data are limited in that they lack detailed MMVF exposure information, smoking history, and other potentially confounding occupational exposures. This report summarises the findings of a case-control study of lung cancer among workers employed at slag wool plants. As well as detailed information on exposure to slag wool fibres, we also collected data on smoking and employment histories outside the MMVF industry.

\section{Materials and methods}

Included in the study were nine plants in the United States that used slag wool in their products. Four of the plants were also in the University of Pittsburgh study. ${ }^{2}$ The remaining five plants were selected on the basis of completeness of employment records, lack of any known heavy use of asbestos in the past, a long history of operation (to allow an adequate latency), and an adequate size of workforce (for efficiency).

Most of these nine plants started making, or using slag wool, or both in the 1940s. Slag is the primary raw material. In two plants copper slag containing some arsenic was used for a period. Four plants 
intermittently used a limited amount of asbestos for a few years in the late 1960s and early 1970s in specific product formations. One plant also used ceramic fibre occasionally for about 20 years. The products made at the nine participating plants included blankets, batts, blowing wool, pipe insulation, glass air filters, ceiling tiles, and baled wool.

During most of the time covered by this study, blast furnace slag from the reduction of iron ore was the primary raw material. Native rock was used at one plant in the 1930s and blended with blast furnace slag until 1952. Two plants used a mixture of blast furnace slag and basalt in the late 1980 s. To simplify the nomenclature of the report all of the product will be referred to as slag wool.

For all men who worked at the nine plants for one year or more, basic information was abstracted from employment records. This included name, social security number, birth date, hire date, and termination date (if appropriate). A cohort of 4841 employees with a minimum duration of employment of one year was identified. Their vital status to the end of December 1989 was checked against the Social Security Administration (SSA) death master file (DMF) and the National Center for Health Statistics (NCHS) national death index (NDI). The DMF consists of 39 million deaths known to SSA since 1937, and NDI consists of all deaths in the United States since 1979. Death certificates were requested from the appropriate states, and causes of death were coded by a trained nosologist according to the 8th revision of the International Classification of Diseases (ICD).

Cases were defined as lung cancer (ICD 162) deaths between 1970 and 1989. The reasons for not including deaths before 1970 were to minimise the difficulties in locating the families and to reduce errors in next of kin recall of smoking and work history. Controls were randomly selected from the remaining deaths. The decision to use dead controls was based on a consideration of comparability of data (mostly recalls) to be collected for cases and controls. For each case a maximum of four controls was randomly selected, matched with respect to plant, race, and date of birth (within five years). Also the controls must have been alive at the time of the case's death. This requirement allowed the controls to have the same potential for exposure as the corresponding case. Matching by plant would reduce any potential confounding associated with the particular plant or locality.

For each of the cases and the controls a detailed work history was obtained that included job titles, departments or work locations, and the corresponding dates. For slag wool fibre concentrations $(\mathrm{f} / \mathrm{cc})$ we relied on two industrial hygiene surveys. The first was sponsored by the National Institute for Occupatonal Safety and Health (NIOSH) and conducted in $1976 .{ }^{5}$
The second was conducted in conjunction with the University of Pittsburgh study during 1977-78. ${ }^{6}$ Both the NIOSH and the Pittsburgh surveys provided fibre concentrations for broad categories of jobs; exposure was assumed to be homogeneous within each category. In the NIOSH classification the average fibre concentration for these broad job categories ranged from 0 to $0.25 \mathrm{f} / \mathrm{cc}$. The corresponding range in the Pittsburgh classification was from 0 to $0 \cdot 21 \mathrm{f} / \mathrm{cc}$.

Jobs held by the cases and the controls were used to create a job dictionary. Every job in this dictionary was then classified into one of the broad categories and the corresponding fibre concentrations were used in estimating exposure. The job classification was done through the use of the dictionary without any knowledge of the case or control state. A cumulative exposure (f/cc-months) was calculated by summing the products of fibre concentration $(f / c c)$ and duration (months) over all jobs. Exposure of the controls was truncated at the time of death of the cases.

To obtain information on smoking as well as employment outside the MMVF industry attempts were made to locate the surviving family members. The sources used were information on employment records, obituaries in old newspapers, a retail credit bureau, co-workers, and death certificates (when appropriate). A questionnaire was mailed to each contact. In some instances repeated mailing was necessary. Follow up telephone calls were made to solicit participation as well as to clarify information in the returned questionnaires. The interviewer was not aware whether the subjects were cases or controls when making the calls. As a measure of quality control, $10 \%$ of the respondents were contacted again and asked about smoking habits and nonMMVF employment. The responses were consistent with the original information obtained. Employment records were also used to supplement data from questionnaires and telephone interviews.

For statistical analysis, relative risks (RRs) (approximated by odds ratios) were calculated for each of the factors of interest. The corresponding $95 \%$ confidence intervals ( $95 \%$ CIs) of the RRs were also calculated using the test based procedure. ${ }^{7}$ To test the association between the factor of interest and risk of lung cancer, $\chi^{2}$ values were calculated. Both stratified and unstratified analyses were carried out. The unstratified analyses ignored the matching of cases with their controls whereas stratified analyses took the matching into consideration. The MantelHaenszel $\chi^{2}$ procedure was used in the stratified analyses. ${ }^{8}$ Analyses were also performed based on the conditional logistic regression. ${ }^{910}$

\section{Results}

Based on employment records provided, a cohort of 4841 men was identified as having worked more than 
Table 1 Causes of death of controls

\begin{tabular}{lc}
\hline Cause of death & No of controls \\
\hline Heart and circulatory system & 55 \\
Cancer (12 sites) & 13 \\
Non-malignant respiratory disease & 12 \\
Urinary tract & 5 \\
Infectious disease & 4 \\
External causes & 4 \\
Digestive system & 3 \\
Diabetes & 2 \\
Total & 98 \\
\hline
\end{tabular}

$\star$ Excluding lung cancer.

Table 2 Characteristics of cases and controls

\begin{tabular}{|c|c|c|c|}
\hline Characteristics & Cases & Controls & Difference \\
\hline No & 55 & 98 & - \\
\hline $\begin{array}{l}\text { Race: } \\
\% \text { White } \\
\text { Average year of birth } \\
\text { Average age }\end{array}$ & $\begin{array}{c}84 \% \\
1918 \\
62\end{array}$ & $\begin{array}{c}86 \% \\
1917 \\
65\end{array}$ & $\begin{array}{l}\text { NS } \\
\text { NS } \\
\text { NS }\end{array}$ \\
\hline $\begin{array}{l}\text { Source of smoking and } n \\
\text { Mail questionnaire } \\
\text { Employment records }\end{array}$ & $\begin{array}{c}\text { IMVF em } \\
76 \% \\
24 \%\end{array}$ & $\begin{array}{c}\text { oyment in } \\
76 \% \\
24 \%\end{array}$ & $\begin{array}{l}\text { rmation } \\
\text { NS } \\
\text { NS }\end{array}$ \\
\hline
\end{tabular}

NS $=$ non significant.

one year at one of the nine slag wool plants. The DMF and NDI identified 504 deaths between 1970 and 1989. Among these, 61 were lung cancer deaths. Individually matched controls were randomly selected from the remaining deaths according to the matching criteria described above. An attempt was made to have a maximum of four controls per case. Primarily due to the small number of deaths for some plants, however, the number of controls per case varied from one to four.

Of the 61 identified lung cancer deaths, we were unable to locate three families, and no matched controls could be found for another three. Thus only 55 cases were included in the analysis. There were 98 controls in total; 27 cases with one control each, 16 with two each, nine with three each, and three with four each. Table 1 presents the causes of death of the controls. As expected, heart disease accounted for about half of the deaths. Table 2 lists the major characteristics of the cases and controls. White men accounted for $84 \%$ of cases and $86 \%$ of the controls. The average year of birth was 1918 for the cases and 1917 for the controls. The controls were slightly older than the cases, but the difference in age at death was not statistically significant. With respect to sources of smoking and non-MMVF employment information, identical proportions of cases and controls were obtained from mail questionnaires $(76 \%)$ and employment records (24\%).

Table 3 summarises the analysis on cigarette smoking. All 55 lung cancer cases were cigarette smokers compared with $79(81 \%)$ controls. Because of the empty (zero) cell for non-smoking cases, the $R R$, approximated by odds ratio, was infinity. An estimate was suggested by adding a half to the cells to avoid division by zero. ${ }^{112}$ This estimate was reasonable for the unstratified analysis, for which only a single summary $2 \times 2$ table was used. The addition of a half to only one table would not have changed the data much. For the Mantel-Haenszel stratified analysis, there would be 55 such $2 \times 2$ tables (one fof each matched set). In this situation a half would have been added to the cells 55 times, which would significantly inflate the number of non-smoking cases (actually zero) and the corresponding RR would be significantly underestimated. For this reason, the Mantel-Haenszel RR was not calculated whenever an empty cell occurred in the summary $2 \times 2$ table.

As indicated in table 3, the RR of lung cancer for cigarette smokers compared with non-smokers was $27 \cdot 23(95 \%$ CI $4 \cdot 23-70 \cdot 42)$. The corresponding unstratified $\chi^{2}$ was 12.096 and the Mantel-Haenszel $\chi^{2}$ was 11.417 ; both were highly significant.

Table 3 Analysis of cigarette smoking

\begin{tabular}{|c|c|c|c|c|c|c|c|c|}
\hline \multirow[b]{2}{*}{ Comparison } & \multirow{2}{*}{$\begin{array}{l}\text { No of } \\
\text { cases }\end{array}$} & \multirow{2}{*}{$\begin{array}{l}\text { No of } \\
\text { controls }\end{array}$} & \multicolumn{3}{|l|}{ Unstratified analysis } & \multicolumn{3}{|c|}{ Mantel-Haenszel analysis } \\
\hline & & & $R R(95 \% C I)$ & $\chi^{2}$ & p Value & $R R(95 \% C I)$ & $\chi^{2}$ & p Value \\
\hline $\begin{array}{l}\text { Cigarette smokers } v \text { non-smokers: } \\
\text { Cigarette smokers } \\
\text { Non-smokers } \\
\text { Total }\end{array}$ & $\begin{array}{r}55 \\
0 \\
55\end{array}$ & $\begin{array}{l}79 \\
19 \\
98\end{array}$ & $27 \cdot 23(4 \cdot 23-70 \cdot 42)$ & $12 \cdot 096$ & 0.001 & 一 & $11 \cdot 417$ & 0.001 \\
\hline $\begin{array}{l}\geqslant 60 \text { pack-years } v \text { non-smokers: } \\
\geqslant 60 \text { pack-years } \\
\text { Non-smokers } \\
\text { Total }\end{array}$ & $\begin{array}{r}26 \\
0 \\
26\end{array}$ & $\begin{array}{l}31 \\
19 \\
50\end{array}$ & $32 \cdot 81(4 \cdot 74-209 \cdot 10)$ & 13.000 & $<0.001$ & - & $8 \cdot 860$ & 0.003 \\
\hline $\begin{array}{l}<60 \text { pack-years } v \text { non-smokers: } \\
<60 \text { pack-years } \\
\text { Non-smokers } \\
\text { Total }\end{array}$ & $\begin{array}{r}12 \\
0 \\
12\end{array}$ & $\begin{array}{l}20 \\
19 \\
38\end{array}$ & $23 \cdot 78(3 \cdot 22-193 \cdot 93)$ & $9 \cdot 135$ & 0.003 & 一 & $1 \cdot 000$ & $0 \cdot 317$ \\
\hline $\begin{array}{l}\geqslant 60 \text { pack-years } v<60 \text { pack-years } \\
\geqslant 60 \text { pack-years } \\
<60 \text { pack-years + non-smokers } \\
\text { Total }\end{array}$ & $\begin{array}{l}+ \text { non } \\
26 \\
12 \\
38\end{array}$ & $\begin{array}{l}\text { smokers: } \\
31 \\
39 \\
70\end{array}$ & $2 \cdot 73(1 \cdot 13-5 \cdot 85)$ & $5 \cdot 703$ & $0 \cdot 017$ & $3 \cdot 22(1 \cdot 29-7 \cdot 99)$ & $6 \cdot 341$ & 0.012 \\
\hline
\end{tabular}


Analyses by pack-years was also carried out. Table 3 presents the numbers of cases and controls with pack-years information. Those who smoked 60 or more pack-years had an $R R$ of 32.81 compared with non-smokers (highly significant). For those who smoked less than 60 pack-years, the $R R$ was 23.78 and the corresponding unstratified $\chi^{2}$ was highly significant. The Mantel-Haenszel $\chi^{2}$ was not significant, however, primarily because of the peculiar distribution of cases and controls within the matched sets. Finally, a comparison was also made between those with 60 or more pack-years and those with less than 60 pack-years or who did not smoke. In this comparison both the unstratified and Mantel-Haenszel analyses gave similar results ( $R R$ of about threefold; and significant at the 0.05 level).

Table 4 presents information on pack-years for cases and controls. Most cases were extremely heavy smokers, with an average of 72.45 pack-years. The average pack-years among the controls were $48 \cdot 41$. The difference in pack-years between the cases and controls was statistically significant ( $t$ test, $\mathrm{p}=0.002$ ).

With respect to slag wool exposure, one case and one control could not be classified due to inadequate employment histories. In analysis by slag wool exposure, both the NIOSH and the Pittsburgh classifications were used. In general the Pittsburgh classification provided slightly lower estimates than the NIOSH classification.

According to the NIOSH classification, 50 (93\%) cases were exposed to slag wool compared with 90 $(93 \%)$ controls. The unstratified RR was 0.97 and this was not significant (fig 1). The Mantel-Haenszel analysis gave similar results, regardless of whether smoking state (smokers $v$ non-smokers) was adjusted for or not. According to the Pittsburgh classification, four additional controls were exposed (fig 1). The corresponding $R R$ was reduced to 0.40 and this was not significant. Again, the Mantel-Haenszel analysis gave similar results.

For duration of exposure to slag wool, an excellent correlation existed between the NIOSH and the Pittsburgh classifications $(r=0.95, p=0.0001)$. Figure 2 shows that no difference existed between the cases and controls for average duration of exposure. Relative risks were also calculated for those with five or more years of exposure compared with those with less than five years of exposure or with no exposure.

Table 4 Information on pack-years

\begin{tabular}{llll}
\hline & $\begin{array}{l}\text { Average } \\
\text { pack-years } \pm S E\end{array}$ & Range & $\begin{array}{l}\text { Nowith } \\
\text { information }\end{array}$ \\
\hline Cases & $72 \cdot 45 \pm 5 \cdot 14$ & $15 \cdot 00-156 \cdot 00$ & 38 \\
Controls & $48.41 \pm 4.83$ & $0-148.00$ & 70 \\
\hline
\end{tabular}

Difference was statistically significant $(p=0.002)$.
Based on NIOSH exposure data

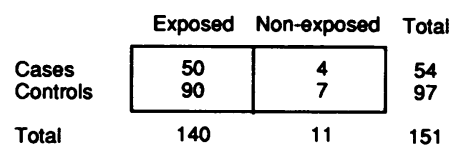

\begin{tabular}{|lccc|}
\hline Method of analysis & RR $(9.5 \% \mathrm{Cl})$ & $\chi^{2}$ & p Value \\
\hline Unstratified & $0.97(0.27-3.49)$ & 0.002 & 0.966 \\
Mantel-Haenszel & & & \\
Unadjusted for smoking (Y/N) & $0.90(0.23-3.49)$ & 0.025 & 0.876 \\
Adjusted for smoking $(\mathrm{Y} / \mathrm{N})$ & $0.94(0.23-3.78)$ & 0.008 & 0.929 \\
\hline
\end{tabular}

Based on Plttsburgh exposure data

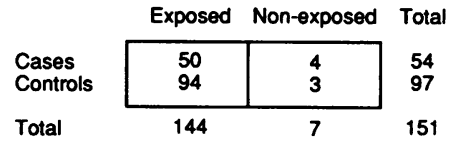

\begin{tabular}{|lccc|}
\hline Method of analysis & RR $(95 \% \mathrm{Cl})$ & $\chi^{2}$ & $p$ Value \\
\hline Unstratified & $0.40(0.09-1.78)$ & 1.451 & 0.228 \\
Mantel-Haenszel & & & \\
Unadjusted for smoking (Y/N) & $0.33(0.06-1.79)$ & 1.643 & 0.200 \\
Adjusted for smoking $(\mathrm{Y} / \mathrm{N})$ & $0.35(0.06-1.98)$ & 1.424 & 0.233 \\
\hline
\end{tabular}

Figure 1 Relation between exposure and risk of lung cancer.

\section{Based on NIOSH exposure data}

Average exposure for cases $=9 \cdot 15$ years Average exposure for controls $=10.14$ years

\begin{tabular}{|c|c|c|}
\hline & $\geqslant 5$ years & $<5$ years \\
\hline $\begin{array}{l}\text { Cases } \\
\text { Controls }\end{array}$ & $\begin{array}{l}23 \\
54\end{array}$ & $\begin{array}{l}31 \\
43\end{array}$ \\
\hline Total & 77 & 74 \\
\hline
\end{tabular}

\begin{tabular}{|c|c|c|c|}
\hline Method of analysis & RR (95\% Cl) & $x^{2}$ & p Value \\
\hline Unstratified & $0.59(0.30-1.16)$ & 2.358 & 0.125 \\
\hline $\begin{array}{l}\text { Mantel-Haenszel } \\
\text { Unadjusted for smoking (Y/N) } \\
\text { Adjusted for smoking (Y/N) }\end{array}$ & $\begin{array}{l}0.61(0.29-1.27) \\
0.74(0.35-1.59)\end{array}$ & $\begin{array}{l}1.751 \\
0.590\end{array}$ & $\begin{array}{l}0.186 \\
0.442\end{array}$ \\
\hline
\end{tabular}

Based on Pittsburgh exposure data

Average exposure for cases $=9 \cdot 15$ years

Average exposure for controls $=10.78$ years

\begin{tabular}{|c|c|c|}
\hline & $\geqslant 5$ years & $<5$ years \\
\hline $\begin{array}{l}\text { Cases } \\
\text { Controls }\end{array}$ & $\begin{array}{l}23 \\
57\end{array}$ & $\begin{array}{l}31 \\
40\end{array}$ \\
\hline
\end{tabular}

\begin{tabular}{|lccc|}
\hline Method of analysis & RR $(95 \% \mathrm{Cl})$ & $\chi^{2}$ & $p$ Value \\
\hline Unstratified & $0.52(0.27-1.02)$ & 3.617 & 0.057 \\
Mantel-Haenszel & & & \\
$\begin{array}{l}\text { Unadjusted for smoking (Y/N) } \\
\text { Adjusted for smoking (Y/N) }\end{array}$ & $0.56(0.27-1.13)$ & 2.623 & 0.105 \\
\hline
\end{tabular}

Figure 2 Relation between duration of exposure and lung cancer. 
Based on NIOSH exposure data

Average exposure for cases $=13.29 \mathrm{f} / \mathrm{cc}$-months

Average exposure for controls $=18 \cdot 29 \mathrm{f} / \mathrm{cc}$-months

\begin{tabular}{|c|c|c|}
\hline & $\geqslant 7 \mathrm{f} / \mathrm{cc}-\mathrm{m}$ & $<7 \mathrm{f} / \mathrm{cc}-\mathrm{m}$ \\
\hline $\begin{array}{l}\text { Cases } \\
\text { Controls }\end{array}$ & $\begin{array}{l}27 \\
54\end{array}$ & $\begin{array}{l}27 \\
43\end{array}$ \\
\hline
\end{tabular}

$\begin{array}{llll}\text { Total } & 81 & 70 & 151\end{array}$

\begin{tabular}{|lccc|}
\hline Method of analysis & $\mathrm{RR}(95 \% \mathrm{Cl})$ & $\chi^{2}$ & $\mathrm{p}$ Value \\
\hline Unstratified & $0.80(0.41-1.55)$ & 0.446 & 0.504 \\
& & & \\
Mantel-Haenszel & & & \\
Unadjusted for smoking (Y/N) & $0.86(0.42-1 \cdot 79)$ & 0.161 & 0.688 \\
Adjusted for smoking (Y/N) & $0.98(0.47-2.04)$ & 0.002 & 0.961 \\
\hline
\end{tabular}

Based on Pittsburgh exposure data

Average exposure for cases $=8.38 \mathrm{f} / \mathrm{cc}$-months

Average exposure for controls $=10.41 \mathrm{f} / \mathrm{cc}$-months

\begin{tabular}{|c|c|c|}
\hline & $\geqslant 5 \mathrm{t} / \mathrm{cc}-\mathrm{m}$ & $<5 \mathrm{f} / \mathrm{cc}-\mathrm{m}$ \\
\hline $\begin{array}{l}\text { Cases } \\
\text { Controls }\end{array}$ & $\begin{array}{l}23 \\
54\end{array}$ & $\begin{array}{l}31 \\
43\end{array}$ \\
\hline Total & 77 & 74 \\
\hline
\end{tabular}

\begin{tabular}{|llcc|}
\hline Method of analysis & RR $(95 \% \mathrm{Cl})$ & $\chi^{2}$ & $\mathrm{p}$ Value \\
\hline Unstratified & $0.59(0.30-1.16)$ & 2.358 & 0.125 \\
& & & \\
Mantel-Haenszel & & & \\
Unadjusted for smoking (Y/N) & $0.65(0.34-1.27)$ & 1.574 & 0.210 \\
Adjusted for smoking (Y/N) & $0.71(0.36-1.41)$ & 0.957 & 0.328 \\
\hline
\end{tabular}

Figure 3 Relation between cumulative exposure and lung cancer.

The analysis showed no association between duration of exposure and risk of lung cancer, with or without adjustment for smoking state.

For cumulative exposure (f/cc-months), the correlation between the NIOSH and the Pittsburgh classification was also high $(r=0.83, p=0.0001)$. The controls had a slightly higher cumulative exposure than the cases, but the difference was not statistically significant (fig 3 ). Neither the unstratified nor the Mantel-Haenszel stratified analysis showed any relation between cumulative exposure and risk of lung cancer. In fig 3 , the groups ( 5 or $7 \mathrm{f} / \mathrm{cc}$-months) were chosen such that the two exposure categories would have a comparable number of study subjects.

As well as the unstratified and Mantel-Haenszel stratified analyses, the conditional logistic regression technique was also used with the actual continuous numbers (pack-years, $\mathbf{f} / \mathrm{cc}$-months, etc). In the first conditional logistic regression analysis, only one variable was put in the model (table 5). Consistent with previous results, pack-years of cigarette smoking were found to be significantly associated with an increased risk of lung cancer. On the other hand, neither duration of exposure nor cumulative exposure to slag wool fibre showed an association with risk of lung cancer.

In the second conditional logistic regression analysis two variables were included in each model (table 6). The variable, "pack-years," was always in the model. Exposure to slag wool fibre was expressed in terms of either duration of exposure or cumulative exposure. An interaction term between pack-years and exposure to fibre was also included, but was subsequently discarded because it did not contribute any information to the model. In all the models presented in table 6 , pack-years remained highly significant whereas neither duration of exposure nor cumulative exposure to fibre showed any association with risk of lung cancer.

As well as histories of exposure to slag wool, we also attempted to collect information on other nonea MMVF employments for the study subjects. We were successful in $50(91 \%)$ cases and $91(93 \%)$ controls. The quality of information varied, however. Table 7 summarises the non-MMVF employment histories by industry. No statistical significance was detected for any industry. For coal mining, the $R R$ was $1 \cdot 69$, but this was not significant.

\section{Discussion and conclusion}

Previous epidemiological studies have found a modest increase in mortality from lung cancer in persons employed in the MMVF industry. This finding was difficult to interpret because of the limitations due to lack of a dose-response relation, lack of detailed exposure information, and lack of

Table 5 Results of conditional logistic regression

\begin{tabular}{|c|c|c|c|c|c|}
\hline Model & Variable & $\beta$ & $\chi^{2}$ & p Value & $R R$ \\
\hline $\begin{array}{l}1 \\
2 \\
3 \\
4 \\
5 \\
6\end{array}$ & $\begin{array}{l}\text { Pack-years } \\
\text { Years smoked } \\
\text { Duration of exposure (Fowler }{ }^{5} \text { ) } \\
\text { Duration of exposure (Esmen et } \text { al }^{6} \text { ) } \\
\text { Cumulative exposure (Fowler }{ }^{5} \text { ) } \\
\text { Cumulative exposure (Esmen } \text { et } \text { l }^{6} \text { ) }\end{array}$ & $\begin{array}{r}0.0226 \\
0.0372 \\
-0.0004 \\
-0.0009 \\
-0.0074 \\
-0.0095\end{array}$ & $\begin{array}{l}7 \cdot 57 \\
5 \cdot 43 \\
0.05 \\
0.33 \\
0.54 \\
0.34\end{array}$ & $\begin{array}{l}0.0059 \\
0.0198 \\
0 \cdot 8208 \\
0.5647 \\
0.4611 \\
0.5604\end{array}$ & $\begin{array}{l}3.05(\geqslant 60 v<60)^{\star} \\
2.10(\geqslant 40 v<40)^{\star \star} \\
0.99 \text { (five years) } \\
0.95 \text { (five years) } \\
0.95 \text { (7 f/cc-months) } \\
0.97 \text { ( } 5 \text { f } / \text { cc-months) }\end{array}$ \\
\hline
\end{tabular}

*Average pack-years for $\geqslant 60$ group $=87 \mathrm{P}-\mathrm{Y}$.

Average pack-years for $<60$ group $=37 \mathrm{P}-\mathrm{Y}$.

$\star \star$ Average years smoked for $\geqslant 40$ group $=50$ years.

Average years smoked for $<40$ group $=30$ years. 
Table 6 Results of conditional logistic regression

\begin{tabular}{|c|c|c|c|c|c|}
\hline Model & Variable & $\beta$ & $\chi^{2}$ & p Value & $R R$ \\
\hline 1 & $\begin{array}{l}\text { Pack-years }(\mathrm{P}-\mathrm{Y}) \\
\text { Duration of exposure }\left(\text { Fowler }^{5}\right)\end{array}$ & $\begin{array}{l}0.0232 \\
0.0009\end{array}$ & $\begin{array}{l}7 \cdot 68 \\
0 \cdot 20\end{array}$ & $\begin{array}{l}0.0056 \\
0.6537\end{array}$ & $\begin{array}{l}3.19(\geqslant 60 \mathrm{P}-\mathrm{Y} v<60)^{\star} \\
1.06 \text { (five years) }\end{array}$ \\
\hline 2 & $\begin{array}{l}\text { Pack-years } \\
\left.\text { Duration of exposure (Esmen et } a l^{6}\right)\end{array}$ & $\begin{array}{r}0.0226 \\
-0.0001\end{array}$ & $\begin{array}{l}7 \cdot 38 \\
0 \cdot 00\end{array}$ & $\begin{array}{l}0.0066 \\
0.9814\end{array}$ & $\begin{array}{l}3.10(\geqslant 60 \mathrm{P}-\mathrm{Y} v<60)^{\star} \\
0.99 \text { (five years) }\end{array}$ \\
\hline 3 & $\begin{array}{l}\text { Pack-years } \\
\text { Cumulative exposure (Fowler }{ }^{5} \text { ) }\end{array}$ & $\begin{array}{l}0 \cdot 0226 \\
0 \cdot 0007\end{array}$ & $\begin{array}{l}7 \cdot 57 \\
0 \cdot 00\end{array}$ & $\begin{array}{l}0.0059 \\
0.9592\end{array}$ & $\begin{array}{l}3 \cdot 10(\geqslant 60 \mathrm{P}-\mathrm{Y} v<60)^{\star} \\
1 \cdot 00(7 \mathrm{f} / \mathrm{cc}-\text { months })\end{array}$ \\
\hline 4 & $\begin{array}{l}\text { Pack-years } \\
\left.\text { Cumulative exposure (Esmen } \text { et } a l^{6}\right)\end{array}$ & $\begin{array}{r}0.0228 \\
-0.0044\end{array}$ & $\begin{array}{l}7 \cdot 58 \\
0 \cdot 05\end{array}$ & $\begin{array}{l}0 \cdot 0059 \\
0 \cdot 8262\end{array}$ & $\begin{array}{l}3.13(\geqslant 60 \mathrm{P}-\mathrm{Y} v<60)^{\star} \\
0.98(5 \mathrm{f} / \text { cc-months })\end{array}$ \\
\hline 5 & $\begin{array}{l}\text { Years smoked (S-Y) } \\
\left.\text { Cumulative exposure (Fowler }{ }^{5}\right)\end{array}$ & $\begin{array}{l}0.0377 \\
0.0050\end{array}$ & $\begin{array}{l}5 \cdot 59 \\
0 \cdot 16\end{array}$ & $\begin{array}{l}0 \cdot 0181 \\
0.6862\end{array}$ & $\begin{array}{l}2 \cdot 13(\geqslant 40 \mathrm{~S}-\mathrm{Y} v<40) \dagger \\
1 \cdot 04(7 \mathrm{f} / \text { cc-months })\end{array}$ \\
\hline 6 & $\begin{array}{l}\text { Years smoked } \\
\text { Cumulative exposure (Esmen et } a l^{6} \text { ) }\end{array}$ & $\begin{array}{r}0.0372 \\
-0.0015\end{array}$ & $\begin{array}{l}5 \cdot 43 \\
0 \cdot 01\end{array}$ & $\begin{array}{l}0.0198 \\
0.9420\end{array}$ & $\begin{array}{l}2 \cdot 10(\geqslant 40 \mathrm{~S}-\mathrm{Y} v<40) \dagger \\
0.99(5 \mathrm{f} / \text { cc-months })\end{array}$ \\
\hline
\end{tabular}

$\star$ Average pack-years for $\geqslant 60$ group $=87$. Average pack-years for $<60$ group $=37$.

+ Average years smoked for $\geqslant 40$ group $=50$. Average years smoked for $<40$ group $=30$.

Table 7 Non-MMVF employments

\begin{tabular}{lllll}
\hline Job/Industry & $\begin{array}{l}\text { No of } \\
\text { cases }\end{array}$ & $\begin{array}{l}\text { \% of } \\
\text { cases }\end{array}$ & $\begin{array}{l}\text { No of } \\
\text { controls }\end{array}$ & $\begin{array}{l}\% \text { of } \\
\text { controls }\end{array}$ \\
\hline Non-MMVF factory work & 14 & 28 & 31 & 34 \\
Manual Labour, misc & 10 & 20 & 24 & 26 \\
Military & 10 & 20 & 17 & 19 \\
Coal mining & 11 & 22 & 13 & 14 \\
Farming & 7 & 14 & 13 & 14 \\
Truck driving & 3 & 6 & 8 & 9 \\
Gas station attendant & 4 & 8 & 7 & 8 \\
Construction & 2 & 4 & 8 & 9 \\
\hline
\end{tabular}

No statistically significant differences were found between cases and controls for any of the above jobs or industries. Example: For coal mining, $R R=1.69, \chi^{2}=0.868$ (non-significant).

Fifty cases and 91 controls had non-MMVF employment information. Some workers had multiple jobs.

controls for cigarette smoking and exposures to carcinogenic contaminants in the manufacturing process. In planning this epidemiological study, we thought that another cohort mortality study that did not cover these issues would not yield any new useful information on the relation between MMVF and lung cancer.

The present case-control study was designed to consider these limitations. Firstly, detailed information on employment was obtained for the study subjects. Quantitative exposure estimates were constructed for study subjects based on two previous industrial hygiene investigations. Secondly, the surviving families of study subjects were interviewed to obtain information on cigarette smoking and employments outside the MMVF industry. Thirdly, only those plants with no heavy use of asbestos in the past were included in the study.

Furthermore, we also thought that a complete ascertainment of all lung cancer cases among employees at the selected plants was essential. Although most of the deaths among active and retired employees were known to the company, we construc- ted the eligible cohort and determined the vital status of the entire cohort including terminated employees. Terminated employees were important because different departments or work areas might have different turnover rates. Thus, without terminated employees, some departments or work areas might be underrepresented.

Matched controls were randomly selected from cohort members who had died from causes other than lung cancer. We considered the option of including living cohort members as controls, but decided against it because information obtained from living subjects might not be comparable with that obtained from families of deceased cases. We examined the distribution of deaths by cause among the controls, and found that causes of deaths were well represented among the controls.

In conducting this study, we found the most time consuming task to be locating and contacting the surviving families because some deaths had occurred almost 20 years ago. In locating the families we relied on a number of sources: company records, co-workers, death certificates (whenever appropriate), SSA, obituaries in old newspapers (working through local librarians) and a retail credit bureau. These intensive efforts were feasible only for a case-control study such as the present investigation. We understand why similar information was not collected in the previous cohort mortality studies.

We were not surprised that all the lung cancer cases smoked but were surprised by their extremely heavy cigarette smoking. Among the cases, the average amount was 72.45 pack-years. Even among the controls a very high proportion smoked, and the average amount was 48.41 pack-years. Given the high proportion of smokers among MMVF workers, it was essential to take smoking into consideration. Furthermore, MMVF workers also tended to smoke extremely heavily; therefore, the amount of smoking (pack-years) should be quantified whenever possible in MMVF studies. 
In our study, we found that cigarette smoking was the significant risk factor for lung cancer among the MMVF workers. A significant dose-response relation was found between pack-years of cigarette smoking and risk of lung cancer. For example, for those MMVF workers with a smoking history of 60 or more pack-years the risk of dying from lung cancer was more than 30 times that of non-smokers.

On the other hand, we did not find any increased risk of lung cancer associated with exposure to MMVF in our study. We examined the relation between risk of lung cancer and exposure to MMVF through several analyses-namely, exposed $v$ nonexposed workers, duration of exposure, and cumulative exposure (f/cc-months). Consistently, no relation was detected in any of these analyses. Also, analyses based on conditional logistic regression did not show any indication of an increased risk of lung cancer associated with exposure to MMVF.

Because the results of the study were negative with respect to exposure to $M M V F$, a discussion of statistical power of the study would be appropriate. To maximise the efficiency of the study, we chose groupings such that the two groups being compared were similar in size. For calculation of statistical power we used the same groupings. At the $5 \%$ significance level (type 1 error), the study had $80 \%$ power to detect an $\mathrm{RR}$ as small as 2.3 between two roughly equal groups. For example, the study had $80 \%$ power to detect an $\mathrm{RR}$ of this magnitude between those workers with more than five years of MMVF exposure and those with less than five years. Thus this study had adequate power $(80 \%)$ to detect an RR of slightly more than twofold, if indeed such a risk existed. The power to detect an RR of less than twofold would be less than $80 \%$.

Finally, we would like to point out some limitations of the study. Firstly, it was based on information from death certificates only and no other diagnostic information was available. Secondly, information about smoking was based on interview data from surviving families and could have been subject to errors associated with memory recalls. Because the information was obtained in a similar fashion from both cases and controls, however, this was unlikely to be a source of bias. Thirdly, the industrial hygiene data were limited particularly for the earlier years of the study when the actual exposures were likely to be higher. Again, because MMVF exposures were assessed similarly for both cases and controls, no bias was introduced. Finally, the fibre concentrations experienced by the MMVF workers in this study were fairly low, and the range of fibre concentrations was narrow. Although these slag wool fibre concentrations are reported to be representative of occupational exposure in the mid-1970s $(0.00$ to $0.25 \mathrm{f} / \mathrm{cc}(\mathrm{NIOSH})$ and 0.00 to $0.21 \mathrm{f} / \mathrm{cc}$ (Pittsburgh)), it may not be appropriate to extrapolate the results to exposures above this range.

In conclusion, we did not detect any increased risk of lung cancer associated with exposure to MMVF, but found cigarette smoking to be responsible for the increased lung cancer mortality in this group of MMVF workers.

We thank USG Interiors, Inc for sponsoring the study; John Hernan, Rod Musselman, and Clyde Roe of USG Corporation for assistance; and Gary Marsh of the University of Pittsburgh for sharing data.

Requests for reprints to: Dr Otto Wong, Applied Health Sciences, 181 Second Avenue, Suite 628, PO Box 2078, San Mateo, CA 94401, USA.

1 Simonato L, Fletcher AC, Cherrie JW, et al. The International Agency for Research on Cancer historical cohort study of MMMF production workers in seven European countries: extension of the follow-up. Ann Occup Hyg 1987;31:603-23.

2 Marsh GM, Enterline PE, Stone RA, Henderson VL. Mortality among a cohort of US man-made mineral fiber workers: 1985 follow-up. J Occup Med 1990;32:594-604.

3 Enterline PE. Role of manmade mineral fibres in the causation of cancer. Br J Ind Med 1990;47:145-6.

4 Rossiter CE, Douglas D. Role of manmade mineral fibres in the causation of cancer. Br J Ind Med 1990;47:646-7.

5 Fowler DP. Industrial hygiene surveys of occupational exposures to mineral wool. US Department of Health and Human Services, Public Health Service Center for Disease Control, NIOSH, Divison of Surveillance, Hazard Evaluations and Field Studies, Cincinnati, OH: 1980. (DHHS (NIOSH) publ No 80-135.)

6 Esmen NA, Corn M, Hammad Y, Whittier D, Kotsko N. Summary of measurements of employee exposure to airborne dust and fiber in sixteen facilities producing man-made mineral fibers. Am Ind Hyg Assoc J 1979;40:108-17.

7 Breslow NE, Day NE. Statistical methods in cancer research. vol 1. The analysis of case-control studies. Lyon: International Agency for Research on Cancer. 1980. (IARC sci publ No 32.)

8 Mantel N, Haenszel W. Statistical aspects of the analysis of data from retrospective studies of diseases. JNCI 1959;22:719-48.

9 Prentice R. Use of the Logistic Model in Retrospective Studies. Biometrics 1976;32:599-606.

10 Prentice R, Pyke R. Logistic Disease Incidence Models and Case Control Studies. Biometrika 1976;66:403-11.

11 Schlesselman JJ. Case-control studies, design, conduct, analysis. New York: Oxford University Press, 1982.

12 Haldane JBS. The estimation and significance of the logarithm of a ratio of frequencies. Ann Hum Genet 1955;20:309-11.

Accepted 8 April 1991 